\title{
The Effectiveness of ASEAN Cooperation in Marine Environmental Protection (MEP) in South China Sea (SCS)
}

\author{
Yoga Suharman \\ International Relations Study Programme, Faculty of Economics and Social Science, Universitas AMIKOM Yogyakarta, Yogyakarta, Indonesia \\ yoga.shrmn@amikom.ac.id
}

\section{Suratih Muhamad Karo}

International Relations Study Programme, Faculty of Economics and Social Science, Universitas AMIKOM Yogyakarta, Yogyakarta, Indonesia suratih.ka@students.amikom.ac.id

Submitted: 21 January 2020; Revised 26 July 2020; Accepted: 15 August 2020

\begin{abstract}
Abstrak
Penelitian ini bertujuan untuk mengkaji kerja sama ASEAN dalam merespon isu-isu terkait keamanan lingkungan laut akibat eksplorasi sumber daya di kawasan Laut China Selatan (LCS). Penelitian ini menganalisis dua aspek keamanan lingkungan, yaitu (1) peran kolektif ASEAN dalam menjaga keamanan lingkungan dan produksi di Laut China Selatan untuk mewujudkan keamanan lingkungan dan manusia, dan (2) efektivitas kerja sama ASEAN dalam menanggapi masalah lingkungan di Laut China Selatan melalui teori efektivitas rezim internasional yang dikembangkan oleh Arild Underdal. Penelitian ini menggunakan metode kualitatif dengan membandingkan perkembangan kerjasama ASEAN MEP dan kapasitas pemecahan masalah sebelum dan sesudah Deklarasi Deklarasi Perlindungan Lingkungan Pesisir dan Laut di Laut China Selatan yang memuat pengaturan kelembagaan, distribusi kekuasaan, kepemimpinan instrumental, dan tingkat kolaborasi antar negara-negara ASEAN, komunitas epistemik, dan perubahan perilaku. Data dan informasi yang diperoleh dari sumber primer berupa dokumen resmi ASEAN dan sumber sekunder berupa jurnal ilmiah dan artikel web. Temuan penelitian ini menunjukkan bahwa kerja sama ASEAN MEP telah berkembang ke arah yangefektif tetapi belum mencapai titik optimal dalam menyelesaikan masalah maritim di Laut China Selatan.

Kata Kunci: ASEAN, efektivitas, kelautan, lingkungan, kerja sama, Laut Cina Selatan.
\end{abstract}

\begin{abstract}
This research aims to examine ASEAN cooperation in responding to issues related to marine environmental security due to the exploration of resources in the South China Sea (SCS) region. This research analyze two aspects of environmental security, consist of (1) ASEAN's collective role in maintaining environmental security and production in the SCS to realize environmental and human security, and (2) the effectiveness of ASEAN cooperation in responding to environmental problems in the SCS through international regime effectiveness theory developed by Arild Underdal. This study utilized a qualitative method by comparing the development of ASEAN MEP cooperation and problem-solving capacity before and after the Declaration for a Decade of Coastal and Marine Environmental Protection in the South China Sea containing institutional setting, power distribution, instrumental leadership, and collaboration level between ASEAN, the epistemic community, and behavioral changes. Data and information obtained from primary sources such as ASEAN official documents and secondary sources consisted of scientific journals and web articles. The findings indicate that ASEAN MEP cooperation has developed towards effectiveness but has not reached the optimum point in solving maritime problems in the SCS.

Keywords: ASEAN, effectiveness, marine, environmental, cooperation, South China Sea.
\end{abstract}

\section{INTRODUCTION}

The development of ASEAN cooperation in environmental protection is divided into several phases. The initial phase began with the launch of the ASEAN Environment Program I in 1977 and II in 1982 (Nguitragool, 2011). Furthermore, the latest development in

ASEAN in the maritime environment is the Declaration for a Decade of Coastal and Marine Environmental Protection in the South China Sea 2017-2027 (ASEAN, 2017). This declaration shows ASEAN's commitment to strengthen cooperation on marine protection in the 
marine protection in the South China Sea (SCS) as an organizational step to maintain environmental sustainability and mark a new chapter of cooperation in carrying out non-traditional security issue regarding the conservation and sustainable management of biodiversity, resources, and marine ecosystem in the SCS. The main points in the declaration include; (1) sustainable use of the coastal and marine environment; (2) responding to and dealing with the risk of pollution and damage to the marine ecosystem and coastal environment ecologically sensitive in the SCS (ASEAN, 2017). Nevertheless, ASEAN maritime cooperation is complex, considering that the dynamics of the SCS region are also related to the traditional security strategic rivalry of regional countries involving the influence of extra-regional powers (Rosenberg, 1999).

There are three main reasons why the SCS is also linked to the traditional security competition for ASEAN members and extra-regional countries. First, the SCS is a shipping route for energy and commodity production valued at $25 \%$ of total global trade (Basu, 2019). Second, the availability of oil and gas reserves with a total of two hundred billion barrels and an estimated value of 750 trillion cubic of natural gas (Kaplan, 2015). It is reinforced by the value of global transactions, reaching \$ 5 trillion annually (Brady, 2017). Third, the availability of food commodities from the marine sector utilized by society inside and outside the region. SCS is a valuable source of production for all countries, both from traditional geopolitics and environmental issues (Bateman et al., 2016; Chircop, 2010). The wealth of the SCS encourages countries around the region to explore resources for the long term as well as utilized as a route of goods exchange across national borders (Suharman, 2019).

The traditional security competition has become the most leading discussion in the SCS. Recently, environmental degradation as a non-traditional security issue took a focus of attention as a concern of global warming increase in the region. . Regional cooperation between ASEAN members and China could minimize the enmity among intersect countries by no longer see SCS as a conflict zone but as a resources area require to be maintained collectively. Cooperation and an effective regional regime will take the SCS out of the environmental degradation.

ASEAN countries are members of the United Nations Convention on the Law of the Sea (UNCLOS), where the convention underlies countries to take national policies and cooperation to protect coastal and marine environments. The existence of the SCS as a strategic resource in the Southeast Asia region has benefited the surrounding countries. However, the exploration and utilization of various production sources carried out by countries around the area have threatened the marine environmental sustainability for the long term. The construction of artificial island by China, global warming, and mangrove forests are factors damaging coastal and marine ecosystems. The mangrove forest area in the South China Sea has decreased by $70 \%$ in the past 70 years, accompanied by a decrease in seaweed habitat from $50 \%$ to 20\% (Chircop, 2010). Intergovernmental Panel on Climate Change (IPCC) stated in their report that in next 30 years $88 \%$ coral reefs in the SCS potentially will vanish due to exploration activities such as the used of explosives also by the effect of global warming (Chircop, 2010). The existence of SCS as an international trade route contributes to the marine ecosystem's problems through the pollution and waste production. The threat of environmental damage in the SCS will significantly affect the stability of Southeast Asia region.

The Declaration for a Decade of Coastal and Marine Environmental Protection in the South China Sea containing norms and principles, is the foundation for ASEAN in dealing with the threat of environmental damage in the SCS. This declaration also underlies the follow-up of ASEAN as a regional organization to implement the norms and principles in the UNCLOS preamble and general provisions concerning state bonds in dealing with and protecting the marine ecosystem (United Nations, 1982a, 1982b). Although ASEAN has taken steps for environmental cooperation toward the Marine Environmental Protection (MEP) in the SCS, the reality shows that the predictions and trends of environmental problems in the SCS appear to be increasing. It raises the question of how effective is 
ASEAN cooperation in implementing the MEP agenda in the SCS?

\section{LITERATURE REVIEW}

At least two previous studies can be developed to understand the dynamics of ASEAN cooperation in responding to maritime damage in the SCS. First, "Advancing Marine Environmental Protection in The South China Sea" (Gong \& Trajano, 2018) focused on initiating regional cooperation in MEP by involving China and ASEAN. In other words, this research dealt with comprehensive cooperation between ASEAN and China as a solution for transnational marine environmental problems in the region.

Second, research conducted by Chircop (2010) on "Regional Cooperation in Marine Environmental Protection in the South China Sea: A Reflection on New Directions for Marine Conservation" (Chircop, 2010) describing threats to the ecosystem and human security as a consequence of climate change and the importance of countries around the SCS to prioritize multilateral cooperation in the marine conservation as the center of all development activities in the region as well as the adaptation measures to climate change under the auspices of the International Maritime Organization (IMO).

The previous study focused on the initiation of cooperation and its mechanisms in handling MEP in a multilateral framework and involved extra-regional organizations. Meanwhile, this research focuses on measuring the effectiveness of regional cooperation on MEP at the ASEAN level by comparing the development of ASEAN MEP cooperation before and after the Declaration for a Decade of Coastal and Marine Environmental Protection in the South China Sea, consist of institutional arrangements, power distribution, instrumental leadership, the collaboration level between ASEAN with epistemic communities, and behavioral change.

\section{THEORETICAL FRAMEWORK REGIME EFFECTIVENESS AND INTERNATIONAL COOPERATION}

An international regime is a form of cooperation containing an agreement of actors in forming an institutional framework, a set of norms and principles of governance, and decision-making procedures stated implicitly or explicitly in solving problems in specific fields (Krasner, 1982). The international regime underlies actors in managing international and regional cooperation in an institutionalized form (Keohane, 1984; Litta, 2012) and simultaneously regulates the actors behavior in a cooperative organization. In practice, the effectiveness of international regimes is influenced by complexity and dynamic factors.

Effectiveness implies the regime's ability to bind actors' behavior in achieving the desired goals. It can be assessed based on the extent to which the norms, principles, and procedures are implemented and the compliance of the obligations stipulated in a regime to each member. There are three main issues in assessing the members' willingness to implement the rules and comply the commitments stated in the regime, i.e. (1) the success of actors to produce outputs in the form of rules, programs, and organization to operationalize provisions, principles, and norms in the regime; (2) outcomes characterized by whether there is a change in actors behavior and units under their jurisdiction who are subject to the obligation in implementing the provisions stated by the regime; and (3) impact related to the level of success in solving problems (Ilkodar \& Mugasejati, 2004). To measure the effectiveness of the ASEAN MEP international cooperation regime in the SCS, this study uses Arild Underdal's (2002) theoretical framework presented in the following table: 
Table 1. The Effectiveness of International Cooperation Regime

\begin{tabular}{|c|c|}
\hline $\begin{array}{l}\text { Independent } \\
\text { Variables }\end{array}$ & Score \\
\hline $\begin{array}{l}\text { Characteristics of } \\
\text { the Problems }\end{array}$ & $\begin{array}{l}\text { - Predominantly benign or at least mixed } \\
\text { - State of knowledge: good } \\
\text { - Predominantly malignant } \\
\text { - State of knowledge: poor }\end{array}$ \\
\hline $\begin{array}{l}\text { Problem Solving } \\
\text { Capacity }\end{array}$ & $\begin{array}{l}\text { High, as indicated by: } \\
\text { - Decision rules provided for the adoption of rules by (qualified) majority } \\
\text { - An IGO with significant actor capacity serving the regime } \\
\text { - A well-integrated epistemic community } \\
\text { - Distribution of power in favor of pushers or pushers + intermediaries } \\
\text { - Instrumental leadership by one or a few parties or by individual } \\
\text { delegates or coalitions of delegates } \\
\text { OR } \\
\text { Low, as indicated by } \\
\text { - Decision rules requiring unanimity or consensus } \\
\text { - Weak IGO serving the regime } \\
\text { - No epistemic community present } \\
\text { - Distribution of power in favor of laggards or laggards and bystanders } \\
\text { - Scant instrumental leadership provided by delegates or coalitions of } \\
\text { delegates }\end{array}$ \\
\hline $\begin{array}{l}\text { Political } \\
\text { Context }\end{array}$ & $\begin{array}{l}\text { Favorable, as indicated by } \\
\text { - Linkages to other benign problems } \\
\text { - Ulterior motives or selective incentives for cooperation } \\
\text { OR } \\
\text { Unfavorable, as indicated by } \\
\text { - Linkages to other malign problems } \\
\text { - No ulterior motives or selective incentives for cooperation }\end{array}$ \\
\hline
\end{tabular}

Note. Processed from Environmental Regime Effectiveness: Confronting Theory with Evidence (Underdal in Miles et al., 2002, p.63, 310).

The explanation of the Underdal's theoretical framework is separated into dependent and independent variables. The dependent variable (regime effectiveness) can be measured based on two propositions, (a) comparing the situation before the existence of the regime, and (b) comparing current conditions. The measurement of the dependent variable can be assessed based on five criteria, consisting (1) there has been a development or a change in members' behavior to be negative or positive; (2) the situation has not changed; (3) progress occurs but is relatively slow; (4) there is a significant change but not major; and (5) there is a significant change in cooperation (Ilkodar \& Mugasejati, 2004).
Meanwhile, the independent variables are divided into two. The first is a problem intellectually easy or difficult for actors to understand. The character of the problem, intellectually hard to understand, will potentially weaken the effectiveness of the regime and vice versa. Second, politically benign vs. malign issues also affect regime effectiveness. As an illustration, politically malign problems have a negative effect on the collaboration level, whereas the collaboration level positively affects the achievement of regime effectiveness. The next independent variable is problem-solving capacity, including institutional setting, power distribution, and instrumental leadership (Underdal in Miles et al., 2002). As an illustration, high problem-solving capacity have a 
As an illustration, high problem-solving capacity have a positive impact on collaboration because high levels of collaboration affected to the effectiveness of the regime.

\section{RESEARCH METHOD}

This study employed a qualitative method aiming to explain a phenomenon by starting from a research question and collecting various data, facts, and behaviors in the research object (Bakry, 2016). This method was used to understand the complexity of a situation and interactions (Creswell, 2013) occurring in the research object, including ASEAN countries and the behavior appearing in the dynamics of maritime environmental security in Southeast Asia and the SCS.

The data were collected using an internet-based method by considering its relevance, validity, and reliability. The data and information obtained in this research were sourced from official documents released by countries and international organizations (Bakry, 2016) such as ASEAN documents, and secondary sources consist of journals and articles relevant to the research theme. In this context, data and facts were interpreted by explaining the phenomena and actors behavior, and then empirical generalizations were drawn to build relationships between concepts, dependent and independent variables concerning the study of the ASEAN MEP cooperation regime in the SCS.

This study is divided into three parts based on several independent and dependent variables adjusted to Underdal's theoretical framework. First, the development of ASEAN in formulating norms and principles for handling maritime environmental problems. Second, analysis of problem types (malign vs. benign) and the members' understanding level to the problems. In other words, an effective regime could be seen when there is low competition, high understanding on certain problem and less complex among the members, and vice versa. Third, the analysis of behavioral changes of the members' to implement the regime at the domestic level.

In this study, the effectiveness of the ASEAN MAP cooperation regime has been assessed based on the problem characteristic which were formulated in the form of a matrix in the following table:

Table 2. Matrix for Measuring Characteristics of Problems in Regime Effectiveness

\begin{tabular}{|c|c|c|}
\hline $\begin{array}{ll} & \text { Type of Problem } \\
\text { Problem-Solving Capacity } & \end{array}$ & Malign & Benign \\
\hline Malign & 3 & 4 \\
\hline Poor & 1 & 2 \\
\hline
\end{tabular}

Note. Adapted from Environmental Regime Effectiveness: Confronting Theory with Evidence (Underdal in Miles et al., 2002).

A scale of 1-4 was applied to depict problem complexity correlating to regime effectiveness. Scale 4 indicates a low level of problem complexity, meaning that if the problem type is benign and the understanding capacity of the actor is good, then it is positively correlated with a high level of effectiveness. Scale 1 shows that the regime is less effective with a high level of malignancy, and the problem-solving capacity is poor. Furthermore, having a scale between 2-3 or the understanding level of actors and problem types is relatively moderate means that the effectiveness of the regime is at the intermediate level.
Moreover, the regime effectiveness indicators can be formulated into six scales based on the collaboration level and actor behavioral changes in the following table 3 .

Based on the Underdal's effectiveness measurement scale, a relationship can be built between the dependent and independent variables based on the effectiveness indicators of ASEAN MEP cooperation. The measurement method was obtained by comparing the development of cooperation before and after the Declaration of the Declaration on the Protection of the Coastal and Marine Environment in the South China 
Table 3. Regime Effectiveness Measurement Scale Based on the Collaboration Level and Behavioral Changes

\begin{tabular}{cl}
\hline Scoring Scale & \multicolumn{1}{c}{ Collaboration Level Indicators } \\
\hline 0 & There is mutual agreement, and no collective action \\
1 & There is a coordination of actions based on unclear understanding \\
There is a coordination of action based on explicitly formulated rules or \\
2
\end{tabular}$\quad \begin{aligned} & \text { Standards but with full implementation in the hands of the national government. } \\
& \text { There is no centralized assessment of the effectiveness of the actions taken. } \\
& 4\end{aligned}$

Note. Adapted from Environmental Regime Effectiveness: Confronting Theory with Evidence (Underdal in Miles et al., 2002).

Sea based on five qualitative criteria comprising (1) there is development or a members behavioral change to a negative or positive direction; (2) there is no change at all; (3) there is relatively slow development; (4) there is a significant change, but not major; and (5) there is a major and optimum change in cooperation.

\section{RESULT AND ANALYSIS THE ESTABLISHMENT OF COOPERATION AND ENVIRONMENTAL REGIME IN ASEAN}

The determinant in the cooperation of an international and regional regime lies in how and under what conditions a regime develops. These two determinants determine how a regime is formed in broad international cooperation and the region in particular. The formation of ASEAN cooperation in the environmental sector was based on the threat of marine environmental degradation in the SCS. ASEAN has developed as an institution containing agreed principles, norms, rules, procedures, and programs to regulate the interaction of actors in the environmental issue (Mushkat, 2012) by adopting higher rules at the global level, i.e. UNCLOS. The Declaration for a Decade of Coastal and Marine Environmental Protection in the South China Sea is the basis for ASEAN in dealing with environmental damage in the SCS and the form of implementing the norms and principles contained in the opening and general provisions of UNCLOS regarding state bonds in handling and protecting the marine ecosystem (United Nations, 1982a, 1982b). Thus, ASEAN is a regional organization with the characteristics of a regime-although it is not yet in a strong legal framework (Mushkat, 2012).

In the last three decades, ASEAN has further deepened its cooperation in environmental protection to respond to trends in ecological damage occurring in the region. The initial phase of environmental cooperation was carried out in the form of the ASEAN Environmental Program I (1977) and II (1982) to protect conservation areas. The second phase of development occurred in the 1990s, aiming to strengthen institutions' capacity to respond to environmental issues through regular meetings. The third phase is the formation of a more formal ASEAN environmental cooperation after the 1990s. Moreover, it includes a Strategic Action Plan on the environment (1999-2004), calling for improving the regional environmental quality and the establishment of ASEAN for biodiversity conservation in 1999 in the Philippines. In the fourth phase, ASEAN launched an Action Plan at the regional level to adopt sustainable development in 2001-2005 (Chandra \& Astriana, 2015; Elliott, 2003). 
For the period 2009 to 2015, the focus of ASEAN environmental cooperation was guided by the Blueprint for the ASEAN Socio-Cultural Community (ASCC), with program priorities on global environmental issues, covering (1) strengthening regional commitments to multilateral environmental agreements; (2) management and prevention of transboundary pollution; (3) increasing public awareness of the environment; (4) promotion of environmentally sound technology; (5) harmonization of environmental policies and databases; (6) improvement of living standards in urban areas; and (7) sustainable use and management of the marine environment including natural resources and freshwater resources, climate change, and forest management (Chandra \& Astriana, 2015).

The Southeast Asia environmental and maritime forums have been generally manifested in the following forms: (1) ASEAN Ministerial Meeting on the Environment (AMME); (2) ASEAN Senior Officials on the Environment (ASOEN); and (3) seven additional working group agencies. AMME meets every two years, while ASOEN and supporting agencies meet once a year to formulate, implement and oversee the ASEAN Strategic Plan for the Environment (ASPEN) and the ASEAN Socio-Cultural Community Blueprint 2025 (ASSC) (ASEAN Secretariat, 2017; Mushkat, 2012).

Furthermore, ASEAN efforts in responding to maritime environmental problems were taken through the Bangkok Declaration on Combating Marine Debris in the ASEAN Region and the Plan of Action to Implement the Joint Declaration on ASEAN-China Strategic Partnership for Peace and Prosperity (2016-2020) item 2.4 (ASEAN, 2019). Besides, the United Nations and the Global Environment Facility (GEF) through the Environment Program had also taken a role to collect research on environmental degradation in the SCS and the Gulf of Thailand from 2002-2008 as an instrument to strengthen cooperation for ASEAN members by involving the role of international organizations outside the region.

Then, ASEAN cooperation in responding to maritime environmental problems in the SCS is outlined in the Declaration of Coastal and Marine Environmental
Protection in the South China Sea (2017-2027). This declaration shows the commitment of each country to combat marine issues such as fishing procedures, illegal fishing, supporting the preservation of the marine ecosystem and efforts to achieve food security (Rocamora, 2017) containing four points related to the preservation and protection of the SCS area, among others; (1) coordinated regional cooperation efforts as the essence of conservation and management of marine resources, biodiversity and the coastal zone of the SCS ecosystem; (2) the importance of protecting natural resources as a basis for current and future economic and social development and recognizing the benefits of making the SCS an area that can provide peace, stability and prosperity; 3) the government's commitment to implement the Declaration on the Conduct of Parties in the SCS, especially in taking cooperative steps toward Marine Environmental Protection (MEP); and (4) the situation of environmental damage in the SCS requires collective attention and action to protect the marine ecosystem and biodiversity, particularly those vulnerable to damage (ASEAN, 2017).

\section{CHARACTERISTICS OF ENVIRONMENTAL PROBLEMS IN THE SOUTH CHINA SEA}

ASEAN is an interesting regional organization due to its status as a group of developing countries and a part of history of European colonialism. Most of the countries in the region are not yet democratic. The level of political stability and economic performance has different characteristics from one another as well as the diversity of religions, ethnicities, traditions, cultures, landscapes, climate, and environmental risks faced by each member. Recently, Southeast Asia has experienced rapid economic growth and development and generally illustrates the success of the region in increasing the wealth of each member. However, at the same time, the region is also facing ecology and environmental degradation (Litta, 2012; Rosenberg, 1999).

There were three environmental degradation problems faced by Southeast Asian countries in the SCS. First, as a consequence of economic-political changes and the increasing mode of production and industrialization. 
Second, the increasing of overfishing in the region (Bateman \& Emmers, 2008). Third, artificial island development activities carried out by China in the SCS. From December 2013 to October 2017, China developed artificial islands with nearly 3200 hectares on seven coral reefs occupying the Spratly Islands in the southern part of the SCS. Vietnam developed 120 hectares of new land, and Taiwan built eight hectares of new land (Smith, Cornillon, Rudnickas, \& Mouw, 2019). To build these islands, Chinese dredgers collected and precipitated sand and gravel on top of coral reefs. These data indicate that the increased activity and utilization of the ecosystem in the SCS have consequences for the emergence of marine environmental problems (Southerland, 2016). International attention to environmental issues in the SCS is a trend of changing recent global political issues related to SDGs, food security, marine resources, and regional ecology.

Furthermore, issues related to the marine environmental security in the SCS are also indicated by data on oil leakage from commercial and fishing vessels and coral degradation resulting from the construction of artificial islands. Consequently, a number of these activities are gradually considered to have threatened the marine ecology of 3.5 million square meters (Jennings, 2017). The SCS is an area with biodiversity and is one of the supplies for food needs in the region and the world.

Moreover, the latest data showed a trend of increasing damage. The SCS area has lost $30 \%$ of seagrass, $16 \%$ of mangroves, $16 \%$ of live corals every ten years. The availability of fish sources was also decreased. There were 10 out of 13 over-exploited fishing locations, particularly in the Philippines, impacting the marine resource and ecosystem (Trajano, 2017). The status of the SCS as a critical shipping route drew attention that the coast of Southeast Asia was one of the most diverse global marine bio-systems in the world, hosting $76 \%$ of the world's coral species and $37 \%$ of reef fish species. In the last two decades, many fishers from China and other countries in the SCS region had engaged in large-scale illegal fishing using cyanide, dynamite, and detonation cables (Singh, 2016).
Based on the data presented above, ASEAN has taken steps to save and protect the marine ecosystem starting from the Strategic Action Plan on the environment (1999-2004) in 1999 in the Philippines until the Declaration for a Decade of Coastal and Marine Environmental Protection in the South China Sea. The action plan and declaration indicate the concern and attention of ASEAN countries toward the environmental damage situation in the SCS and, at the same time, represent a high level of understanding among members. Meanwhile, the level of competition among member countries is low, and the position of ASEAN member in promoting MEP in the SCS are relatively symmetrical. There was no apparent enmity standing out among ASEAN members in responding to environmental security issues other than traditional geopolitical competition.. Therefore, the characteristics of problems related to the damage and protection of the coastal and marine ecosystems in the SCS were politically benign, and there appeared to be a political will be shown by ASEAN that environmental problems in the SCS required collective resolution.

\section{MANAGEMENT AND PROBLEM SOLVING CAPACITY}

The independent variable in measuring regime effectiveness was assessed from the institutional problem-solving capacity. Institutional capacity has been divided into three aspects: institutional setting, power distribution, and also skills and energy possessed consist of instrumental leadership and an epistemic community (Underdal in Miles et al., 2002).

\section{Institutional Setting}

As a regional organization with a cooperation regime, ASEAN has made progress toward a constitutive organization (Mushkat, 2012). In other words, there are arrangements within ASEAN, aiming at improving institutional governance. In this context, the institutional setting is outlined in the form of an agreement between the heads of government of ASEAN members to formulate an ecologically oriented joint plan, among others, a Policy Framework for Environmental 
Cooperation, Environmental Objectives and Strategies, Ministerial Declaration on Environment, ASEAN Environmental Program, ASEAN Action Plan Strategic for Environment, Hanoi Action Plan, Transboundary Pollution, and ASEAN Action Plan for Energy Cooperation, until the establishment of the Declaration for a Decade of Coastal and Marine Environmental Protection in the South China Sea. The joint plan aims to coordinate different interests and exchange information between members through various forums such as the ASEAN Ministerial Meeting on Environment, the highest agency in coordinating and facilitating the handling of environmental issues, and the non-traditional maritime security in the region (Lakshmi, 2018).

The development of ASEAN MEP as an organizational governance has resulted in the agencies under it, including working groups focusing on efforts to address marine problems in the region (CIL, 2019). Realizing how valuable the resources in the SCS are for the needs of people in the region, ASEAN leaders have decided to encourage the conservation and sustainable management of marine and coastal ecosystems, among others, as outlined in the 2005 ASEAN Socio-Cultural Community Blueprint used as a guide for the working group (ASEAN Working Group on the Coastal and Marine Environment-AWGCME) engaged in the management of coastal and marine environmental areas bordering the SCS (CIL, 2019).

AWGCME has a role in ensuring the governance of coastal and marine environments including ecosystems, species, economic activities and environmental education in riparian Southeast Asian countries as well as serving as an arena for negotiations and consultations to coordinate and collaborate among ASEAN members and also ensure that conservation and management are carried out in an integrated and sustainable way. Besides, several working groups related to the protection of the marine environment are involved in ASEAN, such as the ASEAN Sub-Committee on Marine Science and Technology, ASEAN Maritime Transport Working Group, and the ASEAN Maritime Forum also has relevance with the aim of strengthening the effectiveness of marine environmental cooperation. The establishment of an institutional framework involving working groups produce technical guidelines on marine protection, conservation, biodiversity, climate change, and water resources. In simple terms, the framework for ASEAN institutional arrangements in the environmental sector can be described as follows.

The role of the working group in ASEAN management is to develop a management indicator matrix based on the analysis that the sustainable management of coral reefs means that the management of ecosystems aiming to utilize resources can be carried out sustainably with the principles of being environmentally friendly and cost-efficient. In the working group meeting, recommendations have been made, encouraging effective area management against various environmental damage existing in the SCS at the regional organization level.

The integration of ASEAN environmental programs into the overall AMME framework, generally under the ASEAN Political-Security Community (APSC), the ASEAN Socio-Cultural Community (ASCC), and the ASEAN Economic Community (AEC) was carried out based on the Specific Measurable, Achievable, Realistic, and Time-bound (SMART) approach. This institutional arrangement was a step to coordinate policies for members to achieve the goal of solving environmental problems in the region. It indicates that ASEAN has moved to coordinate and collaborate based on an agreement set out in the Declaration for a Decade of Coastal and Marine Environmental Protection in the South China Sea, however, with a note that implementation is entirely in the hands of the national government of each member. In other words, a centralized assessment of the action effectiveness taken by each member did not appear. Even though AMME has the highest hierarchy, but collective decision-making is still shrouded in cultural factors and organizational leadership and the willingness of each members and geographical differences between North and South of the Southeast Asia (Underdal in Miles et al., 2002). centralized assessment of the action effectiveness taken by each member did not appear. Even though AMME has the highest hierarchy, but collective decision-making is 


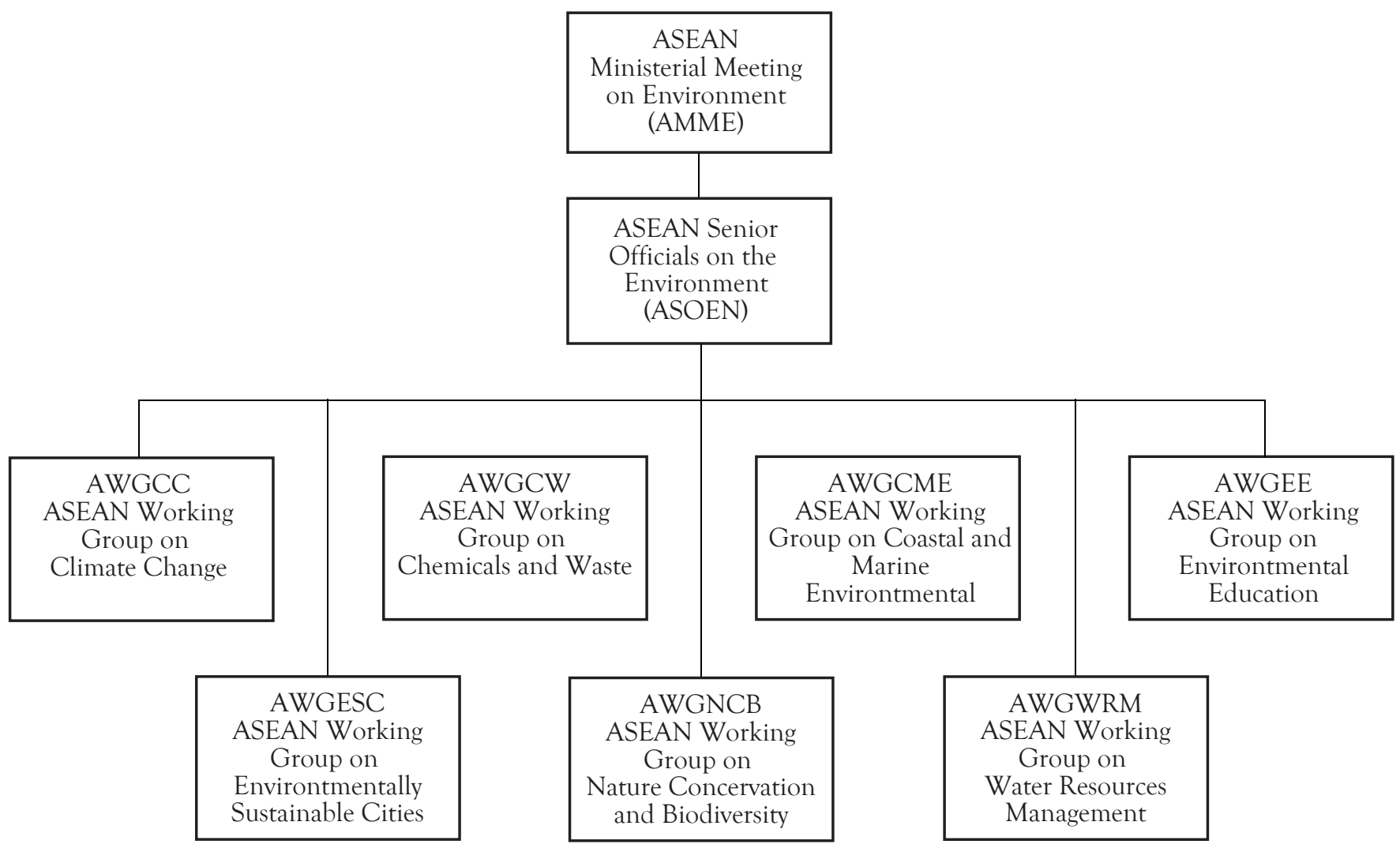

Figure 1. ASEAN Institutional Arrangements on Environment (ASEAN Secretariat, 2017)

still shrouded in cultural factors and organizational leadership and the willingness of each members and geographical differences between North and South of the Southeast Asia (Underdal in Miles et al., 2002).

According to Underdal's (2002) theoretical formulation, ASEAN institutional arrangements could be rated at a scale of two. The argument underlying this assessment was that ASEAN's institutional capacity in general, including in the environmental field, has so far had a limited role in the recommendation provider, coordinator and meeting facilitator for each member and working group involved, but did not have enough central power to influence the overall members decision. Until 2019, there were still three countries that have not integrated with the framework established by ASEAN in the environmental sector, consist of Singapore, Brunei Darussalam, and Laos (MEPSEAS, 2019c). It was a sign of the integration problem and member consensus into explicit and implicit programs and regulations regarding the marine environment in ASEAN, even though integration and consensus are essential determinants for incorporating actor preferences into collective decisions, especially for strengthening capacity and institutional arrangements (Underdal in Miles et al., 2002).

\section{Distribution of Power}

The institutional framework formed was not strong enough to force all members to truly carry out the environmental and maritime security agenda in the ASEAN region and the SCS and to take a collective action as a whole in line with the sustainable development goals and protection in the SCS, not on a voluntary compliance. In fact, according to Underdal (2006), cooperation can be effective if a regime has benevolent hegemon, which can influence all members to carry out the agreement formed (Underdal in Miles et al., 2002).

ASEAN has still adhered to the principles of the ASEAN Way in making decisions without any authority to influence its members' will. Environmental and 
maritime issues in the SCS region could be resolved effectively if the institutional framework and ASEAN leadership have a higher power to make more significant changes and influence them as a whole. Within the ASEAN MEP framework, there is no selective reward to members when integrating themselves into the environmental programs and maritime security agendas. Conversely, they can provide selective sanctions if members do not implement the agreement. It is what has not been seen in the implementation of ASEAN MEP in the SCS.

\section{Instrumental Leadership}

ASEAN has often been criticized because the norms governing the principles of the ASEAN Way are one of the factors influencing changes in collective behavior and the implementation of provisions regarding the marine environmental security in the SCS. As stated by Underdal (2002) that, in general, a regional organization implemented based on voluntary compliance from its members is relatively more difficult to produce collective behavioral change due to the cooperation undertaken.

When each country is faced with a transnational environmental problem, it will led them into two probabilities. First, they can work together to solve problems by determining norms, principles, and policy-making procedures based on legally binding and adopting them into national regulations. Second, they decide not to do so, and member states are not obliged to cooperate according to their respective preferences. In this context, it could be argued that ASEAN required informal and formal leadership, which could influence some members who have not integrated themselves and formulate national policies in line with the agenda and MEP programs in the SCS.

In general, the national policies of ASEAN members are still based on voluntary compliance. In international law, the most fundamental principle is that states cannot be legally binding except based on their agreement, and states do not need to be involved in an agreement if it is not following their interests. This fact confirms that ASEAN's leadership capacity in solving environmental problems in the SCS is likely to be soft. However, it is stil considered reasonable because, as stated by Underdal (2006), and instrumental leadership in an international cooperation regime is only required if the type of problem is at a high level of malignancy. Considering that the ASEAN MEP problem was classified as benign and the members' understanding level and position were relatively balanced, the instrumental leadership role was not necessary, and the effectiveness, in this case, was moderate.

\section{Collaboration between ASEAN and the Epistemic Community.}

The existence of an epistemic community in Underdal's (2002) view plays a role as one of the factors influencing the effectiveness of the regime in increasing collaboration in policy formulation. Epistemic groups contribute to strengthen a common understanding of how the regime should be formed, operated and, at the same time, increasing the skills of members in an international cooperation regime. The higher contribution of the epistemic community in facilitating and assisting members' national policies will led the higher level of effectiveness resulted by the regime.

Think tanks in Southeast Asia focusing on the marine ecosystem have possessed a platform to disseminate their ideas, research, and technology in advancing the marine environmental security in the region and also improve the regime capacity. Technical Working Groups on Marine Scientific Research and Marine Environmental Pollution is an integrative force for ASEAN MEP cooperation. The first idea for the emergence of research collaboration in the marine environment occurred in the third workshop held in Indonesia, which triggered further technical meetings. To date, there have been six technical assistance and two projects to strengthen ASEAN cooperation in preserving biodiversity and monitoring marine ecosystems.

The epistemic community collaborates with the working group to improve the ASEAN MEP problem-solving capacity through expert group meetings and training to formulate steps that need to be carried out immediately. AWGCME has periodically held meetings with expert groups whose results are used as a 
reference in decision making related to coastal and marine environmental management, among others, (1) the ASEAN Conference on Reducing Marine Debris in ASEAN Region in 2017; (2) workshop on the ASEAN Mechanism to Enhance Surveillance Against Illegal Desludging and Disposal of Tanker Sludge at Sea in 2018; (3) regional Workshop on Managing Packaging Waste - Preventing Marine Litter in 2018; and (4) collaboration with the Norwegian Institute for Water Research in a plastic pollution reduction project starting in 2019. An epistemic community collaborating with the environmental working group indicates the very high level of ASEAN MEP collaboration. Theoretically, there was a contribution from epistemic communities to advance the ASEAN MEP cooperation regime in Southeast Asia and the SCS.

Furthermore, at the external level of the region, ASEAN is also collaborate with the United Nations on Environment Program (UNEP) as a representative of the international government organization (IGO) and the Global Environment Facility (GEF), acting as a facilitator and mediator for seven riparian countries bordering the SCS, consist of Cambodia, China, Indonesia, Malaysia, Philippines, Thailand, and Vietnam. The UNEP's role was relatively significant in producing findings on environmental damage and facilitating ASEAN cooperation in the SCS (Chen, 2013). Moreover, the International Maritime Organization (IMO) in 2018 through the Marine Environment Protection for Southeast Asia Seas (MEPSEAS) program has been involved in a partnership with the Norwegian Agency for Development Cooperation (NORAD) for the next four years to improve ASEAN's capability to protect marine environmental security in the region (Nusantara Maritime, 2018). In this dimension, the collaboration between ASEAN, the epistemic community, and IGO has high value.

\section{BEHAVIORAL CHANGES OF ASEAN MEMBERS}

Outcomes characterized by whether there is a change in actors' behavior and units under their jurisdiction who are subject to the obligation to implement the provisions stated by the regime are one of the indicators of the
ASEAN cooperation effectiveness in carrying out the MEP agenda in the SCS. In other words, the effectiveness indicator of international cooperation and regimes can be measured based on criteria regarding how much behavioral changes of members to adopt and implement norms and principles agreed upon in institutional arrangements into national regulations.

ASEAN has made positive progress in realizing MEP in the region. This development reflects that member countries are moved to make behavioral changes in dealing with the existing problems. At least seven ASEAN countries have drafted national regulations as a follow-up to the Declaration of Coastal and Marine Environmental Protection in the South China Sea (2017-2027) and previous agreements in the ASEAN environmental sector, which are Cambodia, Indonesia, Malaysia, Myanmar, the Philippines, Thailand, and Vietnam (MEPSEAS, 2019c). Although Brunei Darussalam, Singapore, and Vietnam not taken MEP policy steps in the domestic sphere, but the majority of ASEAN members has changed their domestic policy.

First, Cambodia's concern of illegal and excessive fishing has resulted in a decrease in fishery stocks in the country. Besides, the destruction of mangrove swamps affecting the country's ecological balance prompted Cambodia to develop a national marine transport policy and draft law to implement the MEP, currently awaiting approval. The Draft Law on the Ocean is Cambodia's action plan in addressing environmental and maritime security issues, showing indicators of state behavioral change in responding to environmental degradation and also represent Cambodia's commitment to carrying out the ASEAN MEP agenda (MEPESEAS, 2019).

Second, the Indonesian government has paid particular attention to environmental protection based on socio-economic interests. A program was developed to promote sustainable use of the marine environment, and, as of 2017, a total area of 19,144,694.28 hectares has been declared a Marine Protected Area (MPA). So far, the Indonesian government has formulated and implemented policies, standards, guidelines, and procedures applicable to Indonesian flagged vessels. Apart from The Directorate General of Sea 
Transportation, other government agencies and industry members are involved in environmental protection activities, such as the Ministry of Environment, society, and academia (MEPSEAS, 2019a).

Furthermore, in 2018 "Our Ocean Conference" held in Bali, the government announced that Indonesia had met its target to conserve 20 million hectares of marine areas, two years earlier. New commitments were made related to improve the maritime security, sustainable fisheries, marine pollution, marine debris management, sustainable blue economy, and climate change adaptation. Then, In the 2018 Intergovernmental Review Meeting on the Global Program of Action for the Protection of the Marine Environment, the delegation continue their commitment to address environmental threats caused by wastewater, marine debris, and microplastics. The Presidential Regulation No. 83/2018 concerning handling marine debris shows Indonesia's national action to commit in carrying out the ASEAN MEP agenda in the region (PEMSEA, 2019).

Third, Malaysia has also developed the Malaysia Master Shipping Plan (MSMP) 2017-2022 to revitalize the five pillars of the maritime sector, including work in the shipping industry, maritime human resource development, and business and environmental regulations within a strategic framework and holistic policy review. The establishment of the law and several institutions under the jurisdiction of the country aim to carry out functions related to the protection of the marine environment (MEPSEAS, 2019b).

Fourth, since 2018, Myanmar has begun to be involved in the development of coastal areas in a sustainable manner and has joined the ASEAN Maritime Transport Working Group (MTWG). The adaptation of maritime transportation policies and the Myanmar marine sector can be assessed by ratifying the convention on marine environmental pollution, i.e. Marine Pollution (MARPOL) Annex I, II, and V (MEPSEAS, 2019d).

Fifth, the Philippines, as a country having 1,557 features of marine protected areas (MPA) was only able to manage 100 areas, and only 541 areas had geographic coordinates for monitoring and law enforcement purposes (Trajano et al., 2018). Hence, there was a need to integrate and coordinate MEP measures to strengthen national laws on MPA to respond the trends of environmental degradation. It was conducted by ratifying the convention on Anti-fouling Systems on Ships and Ballast Water Management (MEPSEAS, 2019e).

Sixth, Vietnam's laws regarding the protection of the marine environment were classified as weak. At least five of the $16 \mathrm{MPAs}$ were adequately managed, the other 21 were considered to be the largest coastal areas in the SCS (Trajano et al., 2018). According to the problems, the Central Party Committee issued the 2015 Law on Marine and Island Natural Resources and the Law on Fisheries, amended in 2017, and designed the Vietnam Maritime Strategy 2020 (Vietnam Law \& Legal Forum, 2018), and developed an innovation program on sustainable development in the context of a marine-based economy (IOC, 2020). In 2019, Vietnam also ratified the Convention on Anti-fouling Systems on Ships and Ballast Water Management (MEPSEAS, 2019g).

Seventh, Thailand is one of the countries facing relatively many environmental hazards, including depletion of water levels, drought, air and water pollution, soil erosion and threats to wildlife caused by illegal hunting, and is one of the largest plastic polluters to the marine environment (WEF, 2020; WHO \& UNFCCC, 2015). Until 2019, Thailand was still in the process of ratifying the London Protocol and Marpol Annex V (MEPSEAS, 2019f).

The domestic steps taken by the seven countries imply that the majority of ASEAN members have shown a commitment to solve marine environmental problems, which can be seen from changes in behavior by ratifying various maritime conventions, formulating regulations, programs, and agendas correlating with handling environment and maritime security in the region. It also reflects the trend of positive changes in ASEAN members when compared to long before the year the Declaration for a Decade of Coastal and Marine Environmental Protection in the South China Sea and other previous agreements related to environmental and maritime protection were declared in the region. Protection in the South China Sea and other previous agreements related to environmental and maritime protection were declared in the region. 


\section{CONCLUSION}

In conclusion, ASEAN has made little progress in implementing the MEP agenda in the region, including the SCS based on four indicators of measuring the effectiveness of the ASEAN MEP cooperation regime. First, the types of problems classified as benign, and intellectually the level of understanding of members toward threats to the environment and marine affairs in the sea areas bordering the SCS was relatively high.

Second, there was an increase in the capacity to solve environmental and maritime problems in the Southeast Asian region bordering the SCS, shown by indicators of positive changes in institutional arrangements, a balanced distribution of power, and minimum instrumental leadership.

Third, the role of expert groups was an essential part of increasing the knowledge capacity of actors (ASEAN members) about various damages to the marine environment in the SCS. ASEAN coordination with the role of experts to increase knowledge about sustainable management of marine resources in the SCS was one of the efforts to encourage more effective cooperation to increase members' skills in implementing norms and principles, both explicitly and implicitly in the ASEAN MEP cooperation. In other words, epistemic groups could have a driving force to increase the level of collaboration between ASEAN members.

Fourth, the effectiveness of the ASEAN MEP cooperation regime was shown by indicators that the majority of members, except for Singapore, Brunei Darussalam, and Laos, have ratified and drafted regulations and maritime development strategies under their respective jurisdictions as members' national commitments and actions toward MEP in the region.

By looking at changes in the behavior of the majority of members in the domestic sphere, generalizations can be built in line with Underdal's theoretical framework about regime effectiveness that ASEAN has progressed toward effective cooperation when compared before and after the Declaration for a Decade of Coastal and Marine Environmental Protection in the South China Sea. However, it should be noted that it has not yet reached an optimal point or a significant and comprehensive change.

\section{REFERENCE}

ASEAN. (2017). Declaration for a Dedace of Coastal and Marine Environmental Protection in the South China Sea (2017-2027).

ASEAN. (2019). Bangkok Declaration on Combating Marine Debris in ASEAN Region. Association of Southeast Asian Nations (ASEAN).

ASEAN Secretariat. (2017). About ASEAN Cooperation on Environment - ASEAN Cooperation on Environment. Association of Southeast Asian Nations (ASEAN).

Bakry, U. (2016). Metode Penelitian Hubungan Internasional. Pustaka Pelajar.

Basu, P. (2019). High tide in the South China Sea Why the maritime rules-based order is consequential ORF. Retrieved December 31, 2019, from Observer Research Foundation: https://www.orfonline.org/research/high-tide-in-the-south -china-sea-why-the-maritime-rules-based-order-is-conse quential-58052/

Bateman, S., \& Emmers, R. (Eds.). (2008). Security and Internation al Politics in the South China Sea: Towards a Co-operative Management Regime. Routledge.

Bateman, S., Nong, H., Erickson, A. S., Ke, X., Shicun, W., Song, Y., \& Jie, Z. (2016). Maritime Security in the South China Sea. In S. Wu, \& K. Zou (Eds.), Maritime Security in the South China Sea. Ashgate Publishing Limited.

Buzan, B., Waever, O., \& Wilde, J. d. (1998). Security: A New Framework for Analysis. London: Lynne Rienner.

Chandra, A. C., \& Astriana, F. (2015). Environmental Protection in the Post-2015 ASEAN Economic Community. Retrieved January 21, 2020, from HEINRICH BOLL STIFTUNG The Green Political Foundation: https://www.boell.de/en/2015 /10/28/umweltschutz-der-

Chen, S. (2013). Environmental cooperation in the South China Sea: Factors, actors and mechanisms. Ocean and Coastal Management, 85, 131-140.

Chircop, A. (2010). Regional Cooperation in Marine Environmental Protection in the South China Sea: A Reflection on New Directions for Marine Conservation. Ocean Development and International Law, 41(4), 334-356.

CIL. (2019). Regional Cooperation for the Protection of the Marine Environment Conference Report. Singapore.

Creswell, J. W. (2013). Research Design: Qualitative, Quantitative and Mixed Methods Approaches. 19(1/2).

Elliott, L. (2003). ASEAN and Environmental Cooperation: Norms, Interests and Identity. Pacific Review, 16(1), 29-52. doi:https://doi.org/10.1080/0951274032000043235

Gong, L., \& Trajano, J. C. (2018). Advancing Marine Environmental Protection in the South China Sea. Singapore.

Ilkodar, S. B., \& Mugasejati, N. P. (2004). Efektifitas Rezim Liberalisme Penanaman Modal Asing Langsung dalam Bank Dunia terhadap Perubahan Perilaku Negara Anggota: Studi Kasus Indonesia (1998 - 2002). Sosiosains, 17(2), 343-363.

IOC. (2020). The World Oceans Day 2020, Vietnam Sea and Island. Retrieved January 23, 2020, from Vietnam National IOC Committee (IOC VN): http://ioc.vn/en/tin-tuc-su-kien/tin-tuc /375-the-world-oceans-day-2020-vietnam-sea-and-island -week-celebrated-from-june-1-8.htm

Jennings, R. (2017). South China Sea Succumbing to Pollution Due 
to Political Impasse. Retrieved December 30, 2019, from https://www.voanews.com/east-asia-pacific/south-china-sea -succumbing-pollution-due-political-impasse

Kaplan, R. D. (2015). Why the South China Sea is so Crucial. Retrieved December 29, 2019, from Business Insider Australia: http://www. businessinsider.com.au/why-the -south-china-sea-is-so-crucial-2015-2

Keohane, R. O. (1984). After Hegemony: Cooperation and Discord in the World Political Economy. New Jersey: Princeton University Press.

Krasner, S. D. (1982). Structural Causes and Regime Consequences: Regimes as Intervening Variables. International Organization, 36(2), 185-205. Retrieved December 30, 2019, from https://doi.org/10.1017/S0020818300018920

Lakshmi, A. (2018). Marine Environment Protection For Southeast Asia Seas Project. Maritime Professional. Retrieved December 27, 2019, from https://www.maritimeprofession al.com/news/marine-environment-protection-southeast-asia $-318938$

Litta, H. (2012). Regimes in Southeast Asia: An Analysis of Environmental Cooperation. Berlin: VS Verlag fur Sozialwis senschaften.

MEPSEAS. (2019). Cambodia. Retrieved December 30, 2019, from MEPSEAS: https://mepseas.imo.org/about/countries/cambo dia

MEPSEAS. (2019a). Indonesia. Retrieved December 30, 2019, from MEPSEAS: https://mepseas.imo.org/about/countries/indone sia

MEPSEAS. (2019b). Malaysia. Retrieved December 30, 2019, from MEPSEAS: https://mepseas.imo.org/about/countries/malaysia

MEPSEAS. (2019c). Maritime Country Profiles. Retrieved December 30, 2019, from MEPSEAS: https://mepseas.imo.org/about /countries

MEPSEAS. (2019d). Myanmar. Retrieved December 30, 2019, from MEPSEAS: https://mepseas.imo.org/about/coun tries/myanmar

MEPSEAS. (2019e). Philippines. Retrieved December 30, 2019, from MEPSEAS: https://mepseas.imo.org/about/coun tries/philippines

MEPSEAS. (2019f). Thailand. Retrieved December 30, 2019, from MEPSEAS: https://mepseas.imo.org/about/countries/thailand

MEPSEAS. (2019g). Vietnam. Retrieved December 30, 2019, from MEPSEAS: https://mepseas.imo.org/about/countries/vietnam

Miles, E. L., Andresen, S., Carlin, E. M., Skjærseth, J. B., Underdal, A., \& Wettestad, J. (2002). Environmental Regime Effective ness, Confronting Theory with Evidence. In Environmental Regime Effectiveness. Cambridge: The MIT Press.

Mushkat, R. (2012). Creating Regional Environmental Governance Regimes: Implications of Southeast Asian Responses to Transboundary Haze Pollution. Washington and Lee Journal of Energy, Climate, and the Environment, 4(1), 103-160.

Nguitragool, P. (2011). Environmental Cooperation in Southeast Asia: ASEAN's Regime for Transboundary Haze Pollution. In Biodiversity \& Conservation (4 ed., Vol. 2). Routledge.

Nusantara Maritime. (2018). ASEAN to Protect its Marine Environment. Retrieved January 21, 2020, from Nusantara Maritime News: https://maritimenews.id/asean-to-protect -its-marine-environment/

PEMSEA. (2019). Indonesia. Retrieved January 21, 2020, from
PEMSEA: http://pemsea.org/about-pemsea/our-part ners/country-partners/indonesia

Rocamora, J. A. (2017). ASEAN-China Adopts Declaration on Marine Environment Protection. Retrieved January 21, 2020, from Philippines News and Information Bureau: https://ww w.pna.gov.ph/articles/1016299

Rosenberg, D. (1999). Environmental Pollution around the South China Sea: Developing a Regional Response. Contemporary Southeast Asia, 21(1), 119-145.

Rosenberg, D., \& Chung, C. (2008). Maritime Security in the South China Sea: Coordinating Coastal and User State Priorities. Ocean Development and International Law, 39(1), 51-68.

Singh, A. (2016). A Looming Environmental Crisis in the South China Sea | Asia Maritime Transparency Initiative. Retrieved December 31, 2019, from Asia Maritime Transparency Initiative: https://amti.csis.org/looming-environmental-cri sis-south-china-sea/

Smith, L., Cornillon, P., Rudnickas, D., \& Mouw, C. B. (2019). Evidence of Environmental Changes Caused by Chinese Island-Building. Scientific Reports, 9(5295), 1-11.

Southerland, M. (2016). China's Island Building in the South China Sea: Damage to the Marine Environment, Implications, and International Law. United States.

Suharman, Y. (2019). Dilema Keamanan dan Respon Kolektif ASEAN Terhadap Sengketa Laut Cina Selatan. Intermestic: Journal of International Studies, 3(2), 127-146. Retrieved January 21, 2020, from https://doi.org/10.24198/intermes tic.v3n2.3

Trajano, J. C. (2017). Marine Environmental Protection and Cooperation: An ASEAN-China Framework?

Trajano, J. C. (2017). Marine Environmental Protection and Cooperation: An ASEAN-China Framework? Singapore: S. Rajaratnam School of International Studies.

Trajano, J. C., Gong, L., Sembiring, M., \& Astuti, R. (2018, February). Marine Environmental Protection in the South China Sea: Challenges and Prospects Part 2. NCT Insight, $1-16$.

United Nations. (1982a). Preamble To the United Nations Conven tion on the Law of the Sea. United Nations Convention on the Law of the Sea of 10 December 1982. United Nations.

United Nations. (1982b). United Nations Convention on the Law of the Sea. United Nations.

Vietnam Law \& Legal Forum. (2018). Vietnam Strives to Become Strong Sea-Based Country. Retrieved from Vietnam Law \& Legal Forum: https://vietnamlawmagazine.vn/viet nam-strives-to-become-strong-sea-based-country-6386.html

WEF. (2020). Thailand is Recycling its Ocean Plastic to Fight COVID-19. Retrieved December 30, 2019, from https://ww w.weforum.org/agenda/2020/07/thailand-coronavirus-cov id19-recyling-innovation-supplies-ocean/

WHO, \& UNFCCC. (2015). Climate and Health Country Profile 2015 - Thailand. Retrieved December 30, 2019, from WHO \& UNFCCC.

Young, O. R. (2011). Effectiveness of International Environmental Regimes: Existing Knowledge, Cutting-edge Themes, and Research Strategies. Proceedings of the National Academy of Sciences of the United States of America, 108(50), 19853-19860. 